\title{
Technology to Frame English Sentences: M-Learning in Language Learning
}

\author{
Lakshmi. K
}

\author{
Research Scholar, English Division, School of Social sciences and Languages, VIT University \\ Vellore, Tamil Nadu India-632014; lakshmikannampurath@gmail.com
}

\section{R. Nageswari}

Assistant Professor, English Division, School of Social sciences and Languages, VIT University Vellore, Tamil Nadu, India-632014; rnageswari.r@gmail.com

\section{Doi:10.5901/mjss.2015.v6n6s1p44}

\begin{abstract}
M-learning has been an establishing method in the language learning since late twentieth century. This paper is an attempt to advocate the efficiency of m-learning to that of traditional learning in Indian context to improve the usage of English sentences. The study also focuses on tertiary level learners' interest in learning English sentence structures which is induced by the mobile devices. The participants for the study are drawn from a private university in Tamil Nadu using convenience sampling method. The study has been carried out using an activity, "Behind the Screen" among the second year tertiary learners. They are provided with activities in two different approaches, traditional and m-learning. The data analysis was done using paired sample t-test in SPSS. The paper shows how m-learning is preferred over traditional learning by young learners during activities in classrooms. The study, thus, proves that the new method in language learning is cordial and confirmatory.
\end{abstract}

Keywords: M-learning, traditional learning, English sentences, tertiary learners, Indian context

\section{Introduction}

M-learning first appeared in the twentieth century as an extension to e-learning. E-learning has been a widespread processing power in the field of education and language learning with the handheld devices in the late $80 \mathrm{~s}$ and $90 \mathrm{~s}$. It grew exponentially as it became more reasonable and even ubiquitous, leading to a new door to learning called $\mathrm{m}$ learning. Mobile devices paved its way in language learning through its computing capabilities and advanced connectivity. With the increased exposure of young learners to the mobile devices and its inexplicable features, this paper aims at enhancing English sentences using m-learning. Though m-learning is considered as just a new way of learning using technology and not a replacement of traditional learning, this study shows a higher hand of the former to the latter.

The studies on m-learning in language learning project the efficacy of the new method in the field of study. Guerrerro, et al. (2010) highlight the use of mobile software tool that was developed to teach grammar to primary education Chilean students. Agca, et al. (2013) established a mobile learning environment combined from printed course book and mobile devices to support vocabulary learning. The instructional materials used in their study mainly composed of "the 7th chapter of the course book. Only cellphone is used as mobile device in the study. Mobile devices used by the students are mostly smartphones and the communication within the classroom is provided via wireless connection" (Agca, et al. (2013), p.783). The case study by Gromik(2012) confirms that the video recording feature of cellphones can also be used for improving the speaking skills. However there have been comparatively lesser studies carried out in Indian context regarding m-learning in language learning. A major study conducted on m-learning in Indian context was a game-based mobile learning model in low- socioeconomic communities of India (Kim, et al., 2012). The study revealed that the learners with no exposure to technology could able to figure out the given mobile technology and solve mathematical problems. Another study by the current researchers on vocabulary learning using m-learning disclosed a better learning environment to the learners outside classroom for English language learning (Lakshmi, et al., 2015). This study thus is an attempt to prove the effectiveness of m-learning in Indian context using task-based approaches. However, the use of mobile devices in this study is not confined to cell phones alone but extended to the use of laptops, tablets, smartphones and notebooks supported by photo editing software.

A feature that the previous studies did not deal with is the study of English sentences using m-learning. Also, they have not yet discussed the lesser acceptance of traditional method among the young learners in being motivated for 
learning process. The major focus of the present study is, thus, the use of m-learning in enhancing English sentence structures. M-learning helps the learners to have a learning environment beyond their classrooms without any constraints to time and place. This paper will show that the new method of m-learning may indeed be an effective way to evoke curiosity and interest in learners on language learning.

\section{Research Methods}

\subsection{Aims of the study}

The purpose of the study was to attempt to figure out a new method that would motivate the learners to frame effective English sentences. It will also investigate how far the new method could be effective when compared to the traditional classroom activities. The end of activity using the new method will also undergo an analysis to check if there were any significant differences between m-learning and traditional learning among the young learners.

\subsection{Context}

This study took place in a private engineering college at Vellore, Tamil Nadu in India. Students from first year classes at tertiary level (age group from 17-19) agreed to undergo the study. The class contained 30 students from B. E Computer Science. The sample was drawn using convenience sampling method. The method was selected for fixing the sample due to the ease of volunteering the study. The target group was assigned with two activities, both in traditional and mlearning methods, that were carried out in five 50- minute lessons. The target learners were with a range of English proficiency. The study was thus an investigation on two different approaches to language learning.

\subsection{Procedures and data analysis}

Two approaches containing one activity each is introduced to the learners in five hours of lessons. All were speaking activities to be performed individually and in group. The first activity was named "Personality pick" in which traditional approach was executed. The learners were asked to choose a personality type of their choice and give a speech for a minimum of one minute on the same. The appropriate use of sentence patterns, coherence, accuracy, clarity and confidence are the five criteria tested in the activity. The first activity was carried out for 50 minutes in two sessions. The second activity named, "Behind the Screen" was implemented in the class using the photo editing applications in mobile devices. The learners were divided into six in each group, as many studies suggest that small groups are better regarding maximum participation and interchange of ideas (Cooper, et al, 1998). The criteria tested in the first activity were followed to evaluate individual's performances. The details of the activities can be found in the Appendix. The learners made audio recordings of their performances in each class during the examining period.

The activity sequences are shown in Figure1. The pre-task hour involved orientation about m-learning, English sentence structures and the type of activities for the study. This was followed by the activity in traditional method. The learners were less confident to present the activities during Activity 1. The group activity in the second phase was carried out with more confidence and enthusiasm by learners. Group work easily supported learners better to elaborate, explain and evaluate information (Dillenburg,et al., 1995). The recordings during the two activities were evaluated using the five criteria mentioned above, in testing the learners' performance in using English sentences. The effectiveness of $\mathrm{m}$ learning has been highlighted at the end of the 5-hours session.

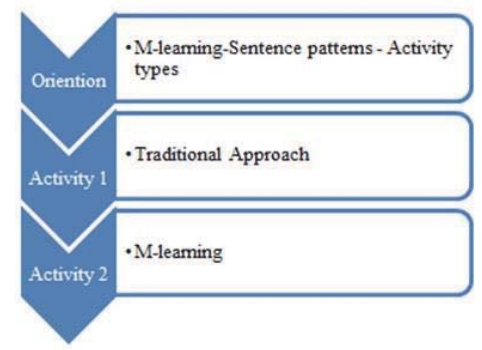

Figure 1. The activity sequence studied in the paper 


\section{Results and discussion}

In Activity 1, the individual choice of their personalities to speak in target language for a minute, involved the space and choice for the learners to successfully deliver their views on the topic. Four choices were given to the learners with their interests on sports, their favourite TV program, their favourite shopping experiences and their favourite food habits. The following features were highlighted during the activity:

- Giving opinions

- Using appropriate sentence patterns

- Having coherence and clarity

- Presenting with confidence

The learners were hesitant to perform individually and their sentences were mostly influenced by their mother tongue. The restricted time to give speech on their thoughts too affected their performance in speech. However, using mlearning there were more attempts to use the target language and they were done with more coherence and accuracy. This is illustrated in (I) and (II) from the two activities which are random examples from the target learners.

I Learner1: .... got topic of 'cloth craver' (.) I mostly don like to shop, shopping (in low voice).

But...eh.... but (.) Nowadays I would like to shop .... Eh.... because of nowadays fashion has changed due to clothings

II Learners2: .... Eh I prefer more ice creams, chocolates (.) eh.... And I hate some vegetables ....

Eh.... Eh .... (Pause for nearly 10 seconds)

The learners were struggling to express their ideas in target language in the first activity. They found difficulty in framing appropriate sentences. In the m-learning activity, there were evidences of being more confident and expressing themselves in appropriate sentence structures with more clarity. When explaining the picture to the other groups, the learners were more interested to describe it to the class. Moreover, the sentences were structured well with clarity. There was also coherence and accuracy in presentation. As the learners were assigned groups for the activity2, their confidence level was also comparatively high.

III Learner 1: A creature is sitting in a sandy region facing to a watery area. It's with mixed colour in complexion.....

The analysis of the performance of the learners in the two activities is summarized in Figure 1, which shows the performance difference and effectiveness of the two approaches. It shows that there has been a comparatively high performance from the learners during Activity2. For Activity 1, Figure1 shows that there were only 4 learners who could score above 15. It also shows how the learners' performance in Activity 2 was higher compared to the Activity in traditional method. It has been found that the learners were more confident to present their ideas confidently in wellstructured sentence patterns. The performance graph of the two activities shows the comparative difference in the effectiveness of both the methods (Figure2).

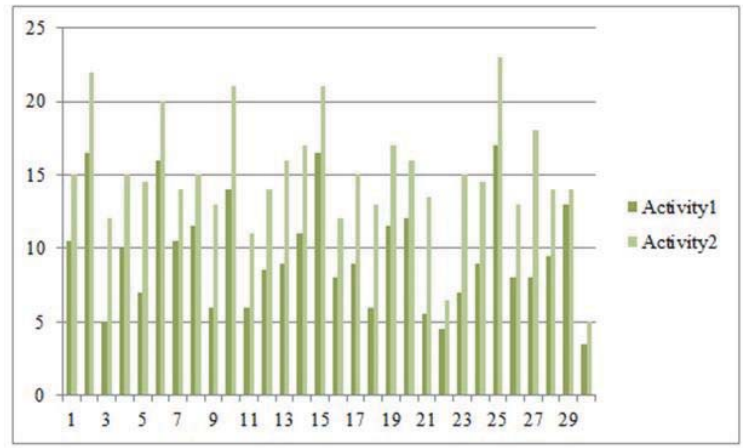

Figure 2. Performance graph of the learners in Activity1 and Activity2

On the whole, the results reveal that there is an increase in the performance level of learners while undertaking $\mathrm{m}$ learning. In Activity2, the learners had clarity in structuring their sentences. They were able to produce their views with 
more clarity. It was also found that students were motivated highly when given an activity through m-devices. The effectiveness of m-learning has thus been widely discussed to be implemented in classrooms.

\section{Conclusion}

This study sought to conclude, whether m-learning as a new method is cordial and authentic in Indian context to improve English sentences among young learners. Indeed, from the data obtained during the activities in two different approaches, there were indications that more attention was paid to m-learning by young learners than traditional classroom learning. This was evident in the performance graph where most of the learners scored better in m-learning activity (Activity2), suggesting the effectiveness of m-learning in classrooms. The analysis further highlights, m-learning can be efficient in Indian context too.

Following the study of Kim, et al. (2012), it has been found that m-learning can ignite exploratory learning through games and activities. This paper, however, explored only the English sentences improving activity. It can also be recommended to extent its study to the other factors to improve speaking skill. The proposed method may also be useful for teachers to implement in their regular classroom teachings to motivate language learning among young learner.

\section{References}

Agca, R. K., \& Özdemir, S. (2013). Foreign language vocabulary learning with mobile technologies. Procedia-Social and Behavioral Sciences, 83, 781-785

Cooper, J., \& Robinson, P. (1998). Small-group instruction in science, mathematics, engineering and technology (SMET) disciplines: A status report and an agenda for the future. Journal of College Science Teaching, 27(6), 383-388

Dillenbourg, P., \& Schneider, D. (1995). Collaborative learning and the Internet. In Published at http://tecfasun1. unige. ch/tecfa/tecfaresearch/CMC/colla/iccaig5 1. html. ICCAl 95

Gromik, N. A. (2012). Cell phone video recording feature as a language learning tool: A case study. Computers \& Education, 58(1), 223230

Guerrero, L. A., Ochoa, S., \& Collazos, C. (2010). A mobile learning tool for improving grammar skills. Procedia-Social and Behavioral Sciences, 2(2), 1735-1739

Kim, P., Buckner, E., Kim, H., Makany, T., Taleja, N., \& Parikh, V. (2012). A comparative analysis of a game-based mobile learning model in low-socioeconomic communities of India. International Journal of Educational Development, 32(2), 329-340

Kothari, C. R. (2004). Research methodology: Methods and techniques. New Age International.

Lakshmi, K., \& Nageswari R. (2015). L2 Learners' Achievement in Acquiring Academic Vocabulary in M-learning Environment. MJAL, 7(1), 19-37

Appendix

Activity 1

PERSONALITY PICK (5 Minutes speech- 2hours)

- Food Fanatic- really love eating

- Sports Fiends- Love to play or watch sports

- Couch Potatoes- prefer watching TV or playing games in computer

- Cloth Cravers- who is fashion conscious and love shopping

- The learners should pick the lot with the above mentioned options

- The learners must deliver a speech related to the selected topic for 5 minutes

Activity 2

BEHIND THE SCREEN- 2 hours- Paint- laptop/ note book-

- Teacher must explain about prepositions and their usages

- The students should be divided into group

- One of the learner in a pair should form an image with a blend of other images

- The other learner of the pair should be provided with clues to guess the object such as, mat under the table, the flower vase is on the table etc

- The same activity should be repeated with switching the role 